\title{
Remembering Tomorrow: Wagon Roads, Identity and the Decolonization of a First Nations Landscape
}

\author{
ERIN S.L. GIBSON
}

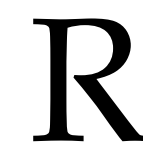

oads embody the experiences of those who construct, use and maintain them through time. This paper explores the social life of a wagon road located in southwestern British Columbia, Canada. Situated between Port Douglas to the south and the Lillooet Lake in the north (Figure 1), this road is best known for its role as a route to the Fraser River Gold Rush in the mid-nineteenth century. I illustrate here that its significance transcends this colonial past. This article explores the roads entanglement in the lives of two contemporary groups: the indigenous Stl'atl'imx (pronounced Stat-lee-um) of the lower Lillooet River Valley whose traditional territories are bisected by the road; and a

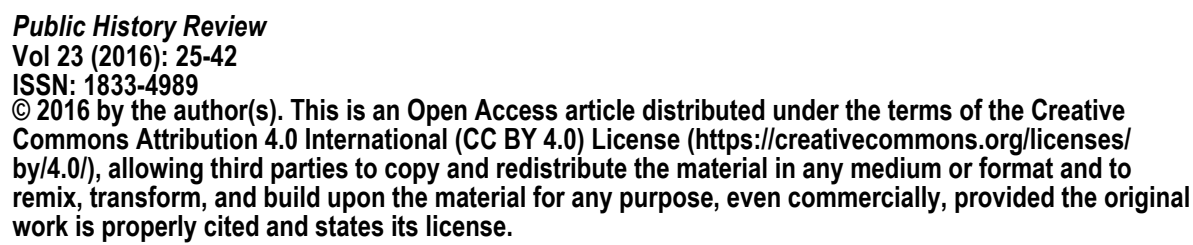




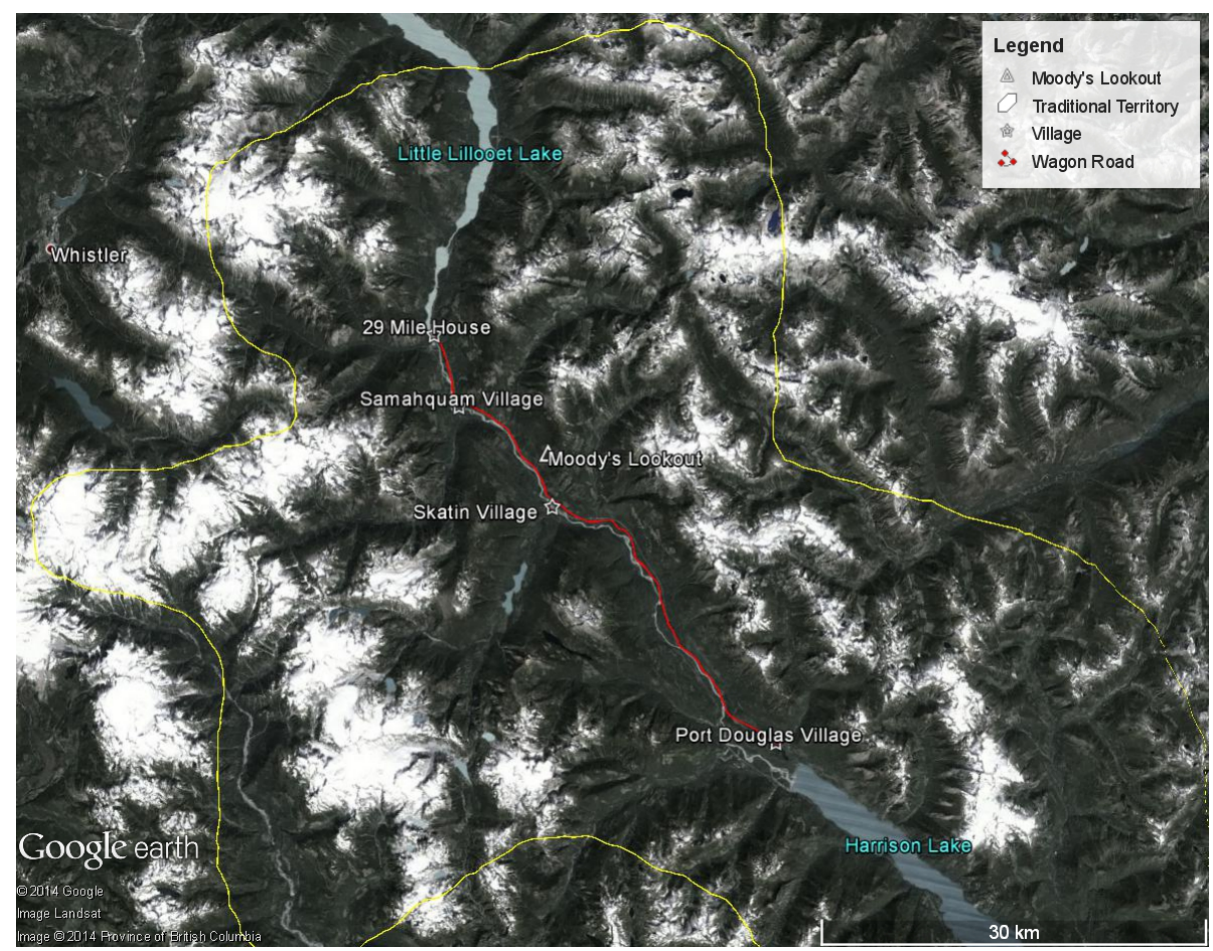

Fig 1 Map showing Traditional Territory of the Stl'atl'imx of the lower Lillooet River Valley, wagon road, and points of interest discussed throughout this article. Google, Landsat 2014: Province of British Columbia

group of non-First Nations (indigenous) Grade 10 high school students from the Langley School District who hike the road as part of their history and geography curriculum. While these two groups differ in their relationship with the road both find meanings through their entanglement with it.

My approach to this wagon road is based on my understanding that roads are material culture or 'things' that both produce, and are products of, complex relationships with the human, non-human and natural world. While roads are shaped through human intentions that inscribe meaning into their design, these same roads influence how humans engage with them - they may cause one to slip, change route or rebuild their surface. In applying a symmetrical approach to the wagon road I highlight its agency and ability to become enmeshed in social relationships in complex ways. ${ }^{2}$

Before delving into the theoretical foundations for this article it is important to provide some cultural background to the Stl'atl'imx of the lower Lillooet River Valley. The Stl'atl'imx are an Interior Salish people who divide themselves into those of the 'upper territory' - including the 
areas around Lillooet - and the 'lower territory' or the lower Lillooet River Valley, the people whose territory ranges from the Harrison Lake in the south to Lillooet Lake in the north. This article focuses on the Stl' atl'imx of the lower Lillooet River Valley who speak the Ucwalmícwts ('oo-Kwale-MEWK) language. They are organised into the Xa'xtsa (pronounced HAHK-cha), Skatin and the Samahquam Nations. In 1993 the political entity of In-SHUCK-ch Nation was created to represent the Stl'atl'imx of the lower Lillooet River Valley in the land claims process with the Government of Canada and province of British Columbia.

Through engaging with the road - building, using and maintaining it - the students and Stl'atl'imx initiated a dialogue among human, nonhuman and the natural world. ${ }^{3}$ It is through this dialogue that the wagon road and those who engaged with it were co-created: they are interdependent and entangled. As Latour states, 'things do not exist without being full of people'.4 In many ways, then, this article is an exploration of heritage - how it is created and embedded through human interaction with the material, non-human and natural world and how it changes through time. While not framed as a discussion of heritage, this article lays the foundations for understanding heritage as both experience and process. ${ }^{5}$

The Harrison-Lillooet wagon road was built by the Royal Engineers in 1859 to provide miners and merchants with a less dangerous route to travel to the Fraser Canyon, the location of the Fraser River Gold Rush. ${ }^{6}$ It replaced a pack trail built in 1858 that is believed to have followed the route of a pre-existing First Nations (indigenous) trail. Mile zero of the Harrison-Lillooet route was Port Douglas, named for the Governor of the Crown Colony of Vancouver Island, James Douglas, located on the northern end of Harrison Lake. While the Harrison-Lillooet road fell out of use for transporting supplies to the goldfields in 1865 after a new Fraser Canyon route was opened, the Stl'at'limx of the lower Lillooet River Valley continued to travel and maintain this road.

In the early 1900s barges regularly transported equipment, groceries and mail to Port Douglas to supply the growing number of logging camps in the area.' Many of the Stl'atl'imx living along the Lillooet River travelled the wagon road - once every two weeks - to Port Douglas from their reserves to the north to obtain their groceries, mail and visit relatives living in the town. The wagon road was replaced as a communication route in 1953 when a new Forestry Service Road was opened. 


\section{REMEMBERING THE WAGON ROAD}

It became evident early on in my research that the wagon road held a place of great significance to the Stl'atl'imx of the lower Lillooet River Valley. I naively arrived to their traditional territories prepared to survey the 1850s 'Gold Rush Road' and discuss its role as a colonising feature in their physical and social landscape. Known mainly for its Gold Rush past, I was under the false assumption that this road would be viewed by the Stl'atl'limx people as colonising, associated with the dispossession of their land and subjugation of their people. Instead, the wagon road was regarded with pride, associated with ancestors, community and tradition (Figure 2). The six years that the road was used as a route to the gold fields meant little in comparison to its role in their daily lives and those of their ancestors in the intervening 150 years. It was the embodied routine (habitus) of using and maintaining the wagon road that created and reaffirmed its place in memory and in their social lives. ${ }^{\mathrm{s}}$

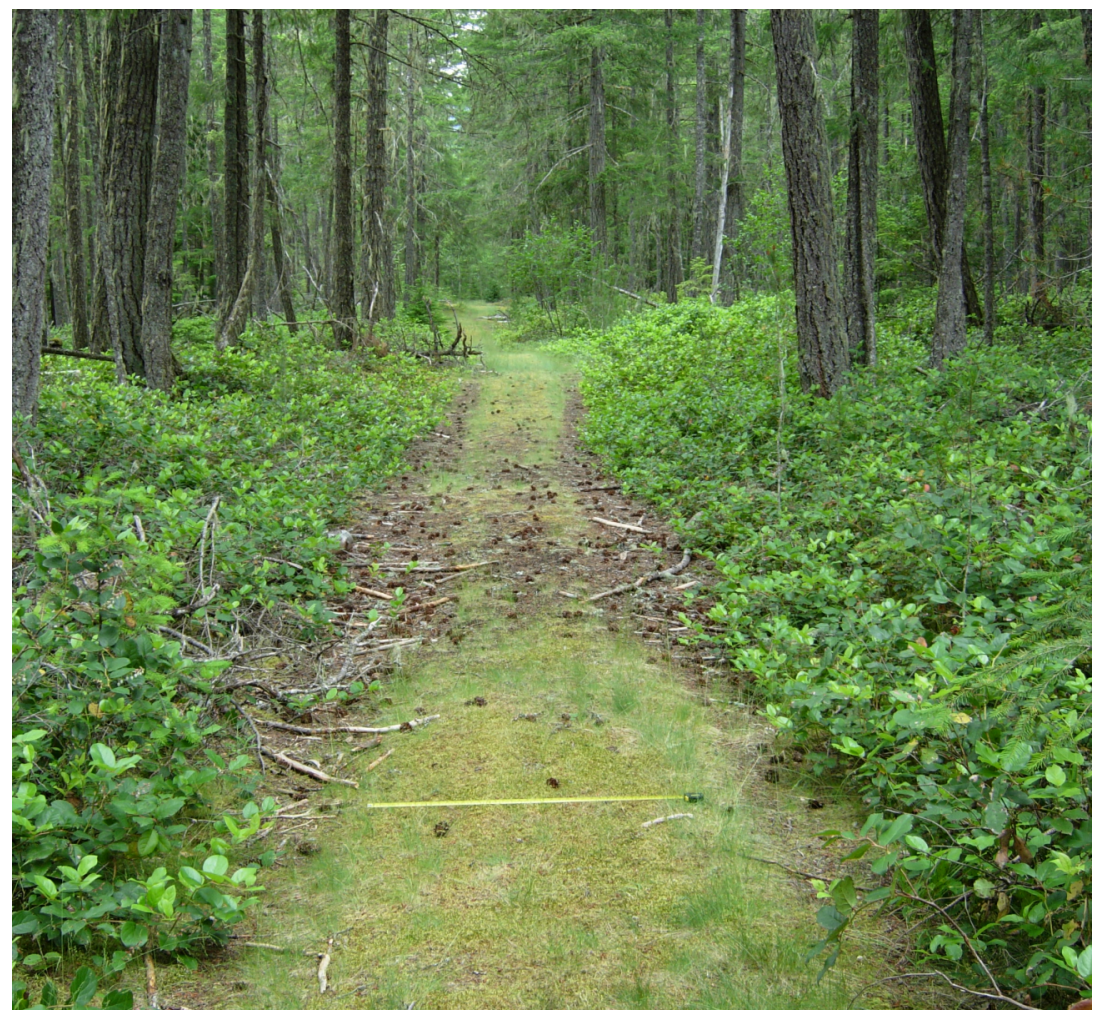

Fig 2 The wagon road, looking north, with 1 metre scale (Photograph the author)

The term 'social memory' highlights how memory is transmitted through individuals as members of larger social groups. ${ }^{\circ}$ Thus there was no one collective memory of the road but instead individual experiences 
and memories were transformed - made social - through the act of sharing. This dialogic process of experiencing, remembering and sharing was the 'work' of memory that was entangled in the materiality and agency of the road. This process that is embedded in and played out through the road established and continues to assert the roads place in local community and belonging. ${ }^{10}$

The entwined nature of the road, the Stl'atl'imx of the lower Lillooet River Valley and non-human world is illustrated in the accounts of Elders who travelled it. As noted above, for the Stl'atl'imx, travelling the wagon road was as much about community and solidarity as it was about the physical journey from 'Point A to Point B'. Their accounts, like that of Elder Lyle Peters, include practical travel details (road conditions, rest stops and difficult hills) alongside social aspects of life (family picnics, fearful places and working together):

It was a very bumpy road; very big boulders sticking out here and there you know... you could see all the campsites, the old fire places depended on how many families you were travelling with. For that long distance my dad and his brothers, we would sort of all travel together you know... And another thing that was so good about that, there was even a 'get together' for families, mingling, storytelling, lots of storytelling, lots of teasing, always lots of teasing."

The life of the wagon road and the Stl'atl'imx of the lower Lillooet River Valley were interwoven and shaped through this entanglement. Weather, vegetation, the slope of the land, the bears, bedrock and wagon wheels were equal players in this messy dialogue. This interdependence among the human, non-human and natural world means that a slight shift in one prompts action in the others. As Hodder states, the 'dependence of things on humans means that humans are always busy along the strings or cables of entanglement fixing things, putting fingers in dykes, fixing holes in buckets, and so on'..$^{2}$ As mentioned previously, it was this embodied routine of using, maintaining and rebuilding portions of this road for over 150 years that created and reaffirmed the road's position of significance in memory and as part of their social lives. ${ }^{13}$

The wagon road shaped those who interacted with it. This transformative nature is evident in oral accounts from Elders who clearly remember those parts of the road that were dangerous, steep or required much labour. As Mills and Walker state, '[p]eople construct social 
memories through their engagement with other people (living as well as ancestral) and through their interaction with varieties of material culture'." For Elder Laura Purcell travel up the steep section of the wagon road called 'Crying Feet' or ilala7cn (pronounced Ilala-HOON) created a strong memory that still influences her relationship with landscapes today:

I remember that road because we always had to get off the wagon because the horses had to make it up there, the team you know. And we would have to walk all the way up that road when I was little... I remember every time I see a cliff with a lot of moss on it, it reminds me of one of the places I would get scared when I was little on the wagons - you go along a cliff there with all the green moss, so every time I see something like that I get a flashback."

While it is vital to acknowledge the impact of interaction among the human, non-human and natural world, and the agency of 'things' in this dialogue, the social relationships negotiated among humans through such interaction is equally transformative. Working together on repairs to the wagon road created and reaffirmed identity as the comments from Elders Frank and Ina Charlie suggest,

It would wash out. They would fix it... tell somebody and they would tell everybody then they all'd go help. They'd help everybody, not like now, eh. You'd get stuck them days, if someone got hungry they'd all get together and bring food to people, if they were hungry.16

Even though the wagon road is no longer used by Frank and Ina Charlie, Lyle Peters, Laura Purcell or the other Elders I interviewed, their lives are still entangled with the road through their acts of 'memory work'..$^{7}$ Memories of the road are recalled, reshaped, forgotten, reinvented and transmitted. ${ }^{18}$ This active process of remembering the road is inseparable from its materiality. Witmore discusses the polychromic nature of landscape, where 'pasts are thoroughly blended into the present; that pasts push back and have an impact within contemporary relations in a multiplicity of ways' ${ }^{\prime 19}$ The material remains of the road are intimately connected to those who used the road in the recent and distant past. As long as the memory and materiality of the road exists it will continue to engage in their lives..$^{20}$ 
Ten years ago the wagon road was cleared of debris and made accessible for foot traffic as part of larger plans to open the road for tourism. Those who participated in this maintenance spoke of the work with pride; they felt good about caring for the road because it was used by their ancestors. ${ }^{21}$ This connection with the road transcends the recent past - through tending the road they are caring for their ancestors. The material culture of the road is inseparable from those who use it, their actions and interactions. It is this embedded and timeless relationship with the material remains of the road that has prompted its inclusion in the In-SHUCK-ch Treaty Settlement Lands with the Provincial and Federal Government.

This wagon road has multiple lives - each emerging through interaction with those who use, build and maintain it. Thus while the footsteps of engineers, gold miners, Stl'atl'imx and students may overlap, they do not share the same road. In the section that follows I discuss how students and their teachers engage with the wagon road and landscape of the Stl'atl'imx of the lower Lillooet River Valley on their annual 'Harrison Hike'. While the experiences of these students are not comparable to those of the Stl'atl'imx whose lives were linked to the road and landscape through daily practice, this example illustrates the complex and entangled nature of materiality, memory, identity and landscape. Even this short-term engagement with the road - walking, repairing, clearing - interacting with fellow students, the non-human and natural world - animals, underbrush, weather - altered how these students see themselves, their place in the world and their future.

\section{THE ANNUAL 'HARRISON HIKE'}

Unlike the Stl'atl'imx who traversed the wagon road as part of their daily lives, the 'Harrison Hike' is an organised, supervised educational excursion that includes walking the wagon road, learning outdoor survival skills, and the history of British Columbia. Teacher and hike leader Grant Inkster describes:

The students must sleep under tarps, prepare meals on an open fire, camp in wilderness locations, gather drinking water, construct latrines, tear down - hike - and set up a new camp each day. In addition, we have activities planned for each day... the students acquire a wide variety of camping skills, learn about B.C. history, experience a semi-wilderness location of our province and learn to appreciate the value of working together as a group to 
accomplish the many tasks required to successfully survive each day. ${ }^{22}$

The first 'Harrison Hike' was organised in 1976 under the leadership of teacher Charles Hou who designed it as part of the Grade 10 social studies curriculum. Today 75 students from Walnut Grove Secondary School in Langley, around $200 \mathrm{~km}$ southwest of the traditional territories of the Stl'atl'imx people, take part in this annual six day hike. The significance of this hike is best illustrated by George Kozlovic who participated on the Harrison Hike in 1987 as a Grade 10 student. Once he finished teacher training at university he ran the hike with Charles Hou. Kozlovic is now principal of Walnut Grove Secondary School, and he still participates in the hike whenever he can: 'while I am no longer actively running the Hike and have only been on the Hike once in the past 9 years, it is still very important to me and a huge part of my life... Two years ago I went on the hike along with my oldest daughter and am hoping to also bring my other two children on the hike in future years'.

Students and teachers become part of a larger dialogue among the human, non-human and natural world through the 'Harrison Hike'. With few outdoor skills these students must adjust to the ever-changing natural and material world while they shift in how they perceive and come to understand this new landscape. The slope of the road, rain, mud, mosquitos, campfire smoke, footbridges and fellow travellers are all entangled and interwoven into their individual experience of the road. This bodily engagement and social interaction transforms how these students see themselves and the world around them. The transformative effect of the 'Harrison Hike' is illustrated when Grant Inkster was asked if he saw students change throughout the hike:

Change would be an understatement. Evolving or morphing into a cohesive family unit would be more appropriate. They start off as a group of independent 2014 teenagers with very little in common. They are stripped of their normal routine and presented with a series of challenges that require them to work together to accomplish. They often struggle, work hard, laugh, cry, celebrate, show compassion and develop camaraderie. They forge bonds and friendships that last through Grade 12 and beyond. ${ }^{2}$

While the 'Harrison Hike' involves many different activities where students engage with their surroundings and each other, walking the 
wagon road - sharing step falls and pace - is as much social as physical. Sharing the rhythm of walking is an intimate encounter that can create bonds among those involved. ${ }^{24}$ It is through the embodied experience of walking that both student identity and physical landscape were shaped; as Lund states, walking is as much about 'exploring oneself as exploring the surroundings'. ${ }^{25}$

Humans never just walk. Walking is only one part of a much larger, complex engagement that includes the natural and material world.

Walking the wagon road requires a deep awareness of the dialogue that exists amongst human, non-human and the natural world and an ability to adjust to their ever shifting actions. Do I move fallen tree branches to the side of the trail for those who pass after me? Is the bridge washed out? Did I bring the correct supplies with me to ford it? Am I going the right direction? Am I making enough noise to scare away the bears? While walking may be a dialogue initiated between the walker and the ground as Vergunst discusses, the material culture of the road - its slope and structure - is inseparable from this embodied experience of walking. ${ }^{26}$ As Lee and Ingold state, walking is an experience 'in which environment shifts and imprints on the body, and is at the same time

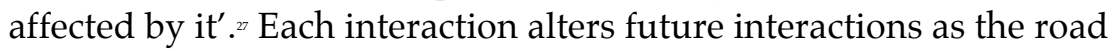
holds a unique position as both 'agent' that directs human action and 'patient' or product of human action. ${ }^{25}$ The wagon road is never the same twice. It is through such entanglement that the wagon road lives out its alternative lives.

The 'Harrison Hike' influences how students come to understand their place in this 'foreign' landscape and their own social worlds. It is a journey made up of 'chains of practices through which humans and nonhumans are connected over time in materially substantial ways' ${ }^{20}$ The hike successfully engages students in the process of co-mingling. Human and 'thing' are blended, shaped, created and reformed throughout it. I emphasize below how the ritual practice of hiking to 'Moody's Lookout' encapsulates this process while illustrating the inseparable link among identity, bodily engagement, materiality and memory.

\section{MOODY'S LOOKOUT}

On day five of the Harrison Hike students climb a mountain to a place called 'Moody's Lookout' (Figure 3). It is named after Colonel Richard Moody of the Royal Engineers who surveyed the wagon road from this mountain. Charles Hou describes the origins of this tradition in an interview taken at the top of Moody's Lookout: 
When Colonel Moody was building the road he came up here to survey up and down the valley because you can see a long way in both directions. And the earliest map I found of this area showed Moody's Lookout on the map so when we got here we decided we needed to hike it. And every year it became a tradition to hike this... on a day when no one really wanted to. Because sometimes it was very hot or else we had been hiking all day but we did it the first year so everybody else had to do it and over the years the tradition developed that we would carry a stone from the bottom to the top of the hill... I have taken over 2000 students up here and there must be another 1000 from other schools that have been up here now and so the students bring their rock and put it here.

And what I used to tell the students to encourage them, because they didn't want to hike this hill, was that if they carry the rock to the top of the hill and put it here that they could do anything they wanted in life because they would know that it was here and they knew that they did something that they didn't really want to do. Now the latest thing is that people are bringing felt pens and they are writing on the rocks so people know...Just about every student who has hiked the Harrison Hike has been up here since 1976. So that's our secret vocabulary. Use 'Moody's Lookout' and no one in the world knows where it is except kids who have been up here. ${ }^{\circ}$

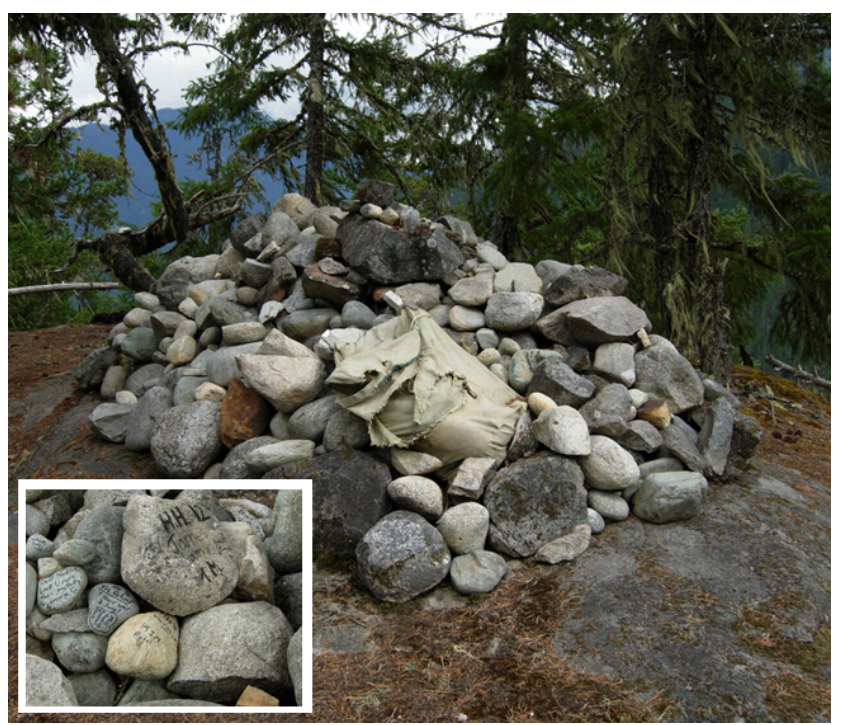

Fig 3 Cairn at Moody's Lookout, looking south down Little Lillooet River Valley 
toward Port Douglas; inset showing writing on stones (Photograph the author) Students became entangled with the non-human world through climbing to 'Moody's Lookout'. This relationship was mutually transformative: each student enters into a personal relationship with Moody's Lookout, and emerges - changed - from it. ${ }^{31}$ Material culture was entangled in this process. As a communal, ritualised and historical practice, the choice of which stone to carry had implications that transcended current social relationships to those in the past and future. The rock - its weight, size - influenced how students climbed the hill and brought meaning to that practice. The rock made a difference student and the 'thingly qualities' of the rock were entangled and redefined through the climb.

Once at the top of the hill students inscribed their rocks. While they all may have participated in this activity they varied in how they chose to memorialise it. Some wrote their full name and date with a brief mention of the experience like 'James Lam T.M. H.H 2012 good times' while others just included a first name 'Emilio', still others left uplifting sentiments such as 'The sun is just one cloud away' and others left messages to loved ones, 'To Jack with love'. While it is impossible to know for sure, the varied inscriptions suggest that not all hikers engaged with their rock or the practice of hiking to Moody's Lookout in the same way. Some chose to commemorate their personal presence and participation while others left messages for those who may hike the hill in the future.

There is a pilgrimage-like quality to the experience of climbing this hill which differs from those experiences recounted by the Stl'atl'imx. While each student experienced the climb differently, the collective practice created a sense of community that transcended the individual student experience. Through following the path and carrying the rock students become connected to those who completed the journey before, as George Kozlovic states:

When many get to the top and see how high they have climbed, they cannot believe what they have just done and feel an enormous sense of accomplishment and pride. And when they see the large pile of rocks at the top that students before them have brought there, they feel like they are part of something bigger... like it is a tradition of great significance and importance. Many have had older brothers and sisters do the hike so they know the importance of this ritual. ${ }^{32}$ 
Once at the top of the mountain rocks are inscribed and added to the ever-changing pile of stones. It is through the intentioned acts of students and teachers that this rock pile becomes a cairn. Applying the concept of citation provides a useful means through which to understand the entanglement of place (cairn) and practice (hike) in social memory. ${ }^{33}$ By walking the hill and contributing their stones to the cairn individuals voluntarily connect themselves to those who participated in the hike before and those who will participate in the future. There is a timeless quality to this practice. The genealogy or multiple histories of the hike are inseparable from the bodily experience of hiking and the material manifestation of this practice - the path and cairn. Climbing Moody's Lookout and adding personalised rocks to the cairn reaffirms the important place of the Harrison Hike in both social memory and the physical landscape.

Ashmore fruitfully discusses the multiple and overlapping biographies of place at the Maya site of Quiriguá Gautemala thus providing insight into the shifting meanings and multivocality of places. ${ }^{34}$ As she discusses, some meanings may be intentionally created as individuals build, use and maintain places while others accumulate meaning from events and experiences that occur in that place. ${ }^{.5}$ The hike to Moody's Lookout - the pathway and cairn that marks the top - is such a place of accumulated histories. The students create and embed meanings as they inscribe their stones and place them on the cairn while others are created through the act of hiking, standing at the top of the mountain and sharing their experiences with fellow travellers.

This cairn, like the wagon road, has multiple lives - it is the materialization of the repeated practice of hiking Moody's Lookout while at the same time writings on its individual rocks suggest that it is commemorative of the 'Harrison Hike' in general. ${ }^{20}$ While the rocks will remain to remind future students of their significance, their individual messages will fade with time. The rock cairn is what Argounova-Low would call a memory link. ${ }^{37}$ Embedded in the cairn are the timeless relationships with the human and non-human world that were entwined and played out throughout the 'Harrison Hike'. Climbing Moody's Lookout encapsulates the meaning of the 'Harrison Hike' to students and teachers alike - while individuals are transformed through the hike it is the collective experience that is remembered most clearly.

So far I have described two very different, though equally significant, accounts where human lives are entangled with the wagon road and its landscape. In a biographical sense these are but two of the many 'lives' of the wagon road. ${ }^{.3}$ While these experiences varied in their intensity and materiality they are similar in their transformative nature. 
For both, the wagon road is catalyst for identity, feelings of belonging and understanding of ones place in the world. While the Stl'atl'limx of the lower Lillooet River Valley, and the Grade 10 students and teachers like Charles Hou, Grant Inkster and George Kozlovic may see the road as holding a place of significance in their lives, one must ask what this 'significance' really means.

\section{THE HeRITAge OF THE 'HeRITAge TRAIL'}

When Charles Hou and his students arrived to Port Douglas to begin the hike in 1989 they found that the last remains of the Gold Rush past at that site had been bulldozed by a mining company. To protect the wagon road and its associated Gold Rush sites from future harm Hou and his students petitioned the provincial government and rallied public support to have the wagon road given official 'Heritage Trail' status. Consequently, the wagon road was awarded this status - the third such trail in the province of British Columbia to be given this designation - in 1991. As a 'Heritage Trail' the wagon road was protected under the conditions of the Heritage Conservation Act, management was transferred to the provincial government, and permits became necessary for any forestry practices or development 100 metres to either side of the road.

Even though the wagon road bisects their traditional territory, the Stl'atl'imx of the lower Lillooet River Valley were never consulted by teachers, students or the provincial government about plans for its preservation. While many would have supported preserving the wagon road, this reclassification was a colonial act that prioritised a statesanctioned concept of heritage over that of the Stl'atl'imx who, for the preceding century had been the de facto users and caretakers of the road. ${ }^{39}$ However, according to the province of British Columbia a Heritage Trail is one of 'historical significance' - in this case it was the Gold Rush or colonial past that made the wagon road 'legitimate' or worthy of management and conservation..$^{* 0}$

While the road was preserved for its past life as a route to the Fraser River Gold Rush, its significance transcends this past. Its heritage value emerges through the relationships in which it is entwined in the 'here and now'. As Harrison states, 'heritage is primarily not about the past, but instead about our relationships with the present and the future'." Heritage as discussed here is a process that changes through time, not a static outcome. ${ }^{2}$ The Harrison Hike where students engaged in relationships with fellow humans, the environment, animal and nonhuman 'things', is the embodiment and expression of such a concept of 
heritage where meanings and values are passed on, reaffirmed and created anew. ${ }^{43}$ The ritualised practice of hiking to Moody's Lookout is a valuable example of how heritage is created through the active choice of objects, places and practices that are viewed as significant to the present and to the future." Thus while students and teachers pushed for the preservation of the road because of its historic past, it was their presentday interactions that gave the Harrison Hike its meaning and value.

The importance of the wagon road to the Stl'atl'imx of the lower Lillooet River Valley goes beyond official definitions of what 'heritage' is or is not. The wagon road holds an important place in their social landscape linking people from the past and present together. ${ }^{.5}$ Here heritage and memory are tightly linked. Remembering and sharing stories of building, using and tending the wagon road is part of making, conserving and nurturing heritage. ${ }^{46}$ It is through the active process of remembering that the meaning and significance of the wagon road is negotiated. ${ }^{\sharp}$ While students may walk the road and transform themselves through this practice, the Stl'atl'imx of the lower Lillooet River Valley are part of the road itself. Their stories tell of how their lives are entwined and entangled in the road - as they are with other parts of their landscape, its human and material aspects - in a way that cannot be detached from who they are. While they may leave their traditional territories, they take the road with them.

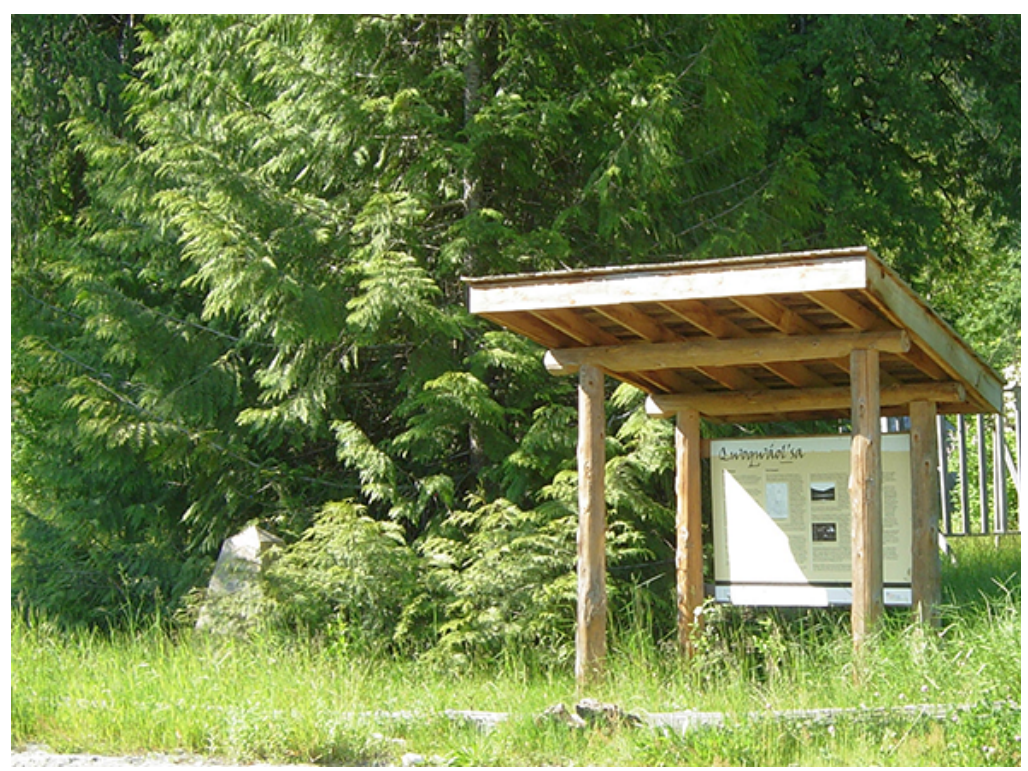

Fig 4 Information board at Qwoqwáol'sa (Port Douglas) with cairn commemorating the Gold Rush in background (Photograph the author) CONCLUSION: PART OF OUR HISTORY AND OUR FUTURE 
The wagon road is both a physical and cultural anchor in the landscape of the Stl'atl'imx of the lower Lillooet River Valley. It is for this reason that it is part of the In-SHUCK-ch treaty with the Provincial and Federal Government. The mid to northern section of this road is included in the 'Treaty Settlement Lands' and its management is part of their 'Final Agreement' with the Governments of British Columbia and Canada. As part of this agreement they must define their heritage, and then adopt a plan to manage it. In an article from the local Úcwalmicw Newsletter David Carson states 'In-SHUCK-ch has been working... to preserve this important element of our history and to ensure that the trail contributes in a good way to our future'. ${ }^{48}$

Information boards such as the one shown below at Qwoqwáol'sa (pronounced koh-Kwal-sah) or Port Douglas (Figure 4), tells the history of the First Nations village and people who lived in this area before colonial contact. Similar signs have been erected along significant parts of the wagon road to highlight the Ucwalmícwts (pronounced InSHUCK-ch) culture and history. This new information kiosk commemorates a different past to what is written on the overgrown cairn located to its left which reads:

\section{PORT DOUGLAS}

In 1958, the start of the gold rush, the Cariboo Trail ran from here to Lillooet on the bank of the Fraser River. This gold rush town was the jumping off place for thousands until 1863-65 when the Fraser Canyon Road turned traffic through Yale. Erected by

The Agassiz-Harrison Board of Trade

Department of Recreation and Conservation 1960

Gaining control of the wagon road is part of reclaiming their traditional territory, reconnecting with their ancestors and thus identities born of that land. Laurajane Smith discusses this link among heritage and place; heritage is more than the creation of identity, it is about 'helping us position ourselves as a nation, community or individual and our 'place' in our cultural, social and physical worlds' ${ }^{\prime}{ }^{.}$Through reclaiming their heritage trail the Stl'atl'imx of the lower Lillooet River Valley are decolonizing their landscape and regaining a sense of identity and belonging. ${ }^{50}$

In many ways this article is an exploration of heritage - how people from different social landscapes were transformed through initiating a dialogue with a road, its landscape, fellow humans and the natural world. I have addressed how material culture is entangled in this process of making meaning. As argued throughout, the materiality of the 
wagon road shifted through its entanglement in the lives of the Stl'atl'imx and the 38 years of Grade 10 students who completed the Harrison Hike. Embedded in the tangible 'things' of these experiences (ruts in the road, campfire hearths, mossy cliffs, rock cairns) are the intangible - the meanings, emotions, memories and knowledge that continues to connect individuals like Elder Laura Purcell and student/ principal George Kozlovic to the road and its landscape. ${ }^{.1}$

\section{ACKNOWLEDGEMENTS}

This article was presented as a paper in part in the Archaeologies of Identity and Memory session at the Society for Historical Archaeology in Quebec in 2014. I thank Tracy Ireland and Jane Lydon for organising this session and inviting this submission. This research was produced in collaboration with In-SHUCK-ch Nation, Skatin (Chief Pat Williams), Samahquam (Chief Brenda Lester) and Xa'xtsa or Douglas Nations (Chief Don Harris). I am grateful for their continued support of this research. I am thankful to Elders Frank and Ina Charlie, Lyle Peters, Laura Purcell and to community member Sydney Hunter for the time they took to speak with me and the stories they shared. Charles Hou, Grant Inkster and George Kozlovic provided invaluable information on the Harrison Hike. Special thanks must go to Stephen Jimmie, Allen Gabriel, Gerard Peters, Lyle Leo, and Josh Alexander for their practical assistance and to Richard Lazenby for comments on an earlier draft. This article was prepared through a Social Sciences and Humanities Research Council (SSHRC) Postdoctoral Fellowship.

\section{ENDNOTES}

Jody Joy, 'Reinvigorating Object Biography: Reproducing the Drama of Object Lives', in World Archaeology vol 41, no 4, 2009, pp544-45 and Yvonne Marshall, 'The Social Lives of Lived and Inscribed Objects: a Lapita Perspective', in The Journal of the Polynesian Society, vol 117, no 1, 2008, pp63-4.

2Alfred Gell, Art and Agency: An Anthropological Theory, Clarendon Press, Oxford, 1998, Bruno Latour, Pandora's Hope: Essays on the Reality of Science Studies, Harvard University Press, Harvard, 1999, Bruno Latour, 'The Berlin Key or How to do Words with Things', in Paul Graves-Brown (ed) Matter, Materiality and Modern Culture, Routledge, London, 2000, p10-21, and Bjørnar Olsen, 'Symmetrical Archaeology', in Ian Hodder (ed) Archaeological Theory Today, Polity, Cambridge, 2012, pp208-28.

Gell, op cit, p17-18, Chris Gosden and Yvonne Marshall, 'The Cultural Biography of Objects', in World Archaeology vol 31, no 2, 1999, pp172-73 and Joy, op cit, p543.

${ }^{4}$ Latour, op cit, 2000, p10.

${ }^{5}$ Laurajane Smith, Uses of Heritage, Routledge, London, 2006, pp47-48.

- Victoria Gazette, 24 July 1858.

- Arnold McCombs and Wilfrid Chittenden, The Harrison-Chehalis Challenge, Treeline Publishing, Harrison Hot Springs, 1988 and Daphne Sleigh, The People of the Harrison, Abbotsford, British Columbia, 1990.

\& Pierre Bordieu, The Logic of Practice, Polity Press, Cambridge, 1990, Marcia-Anne Dobres, Technology and Social Agency: Outlining a Practice Framework for Archaeology, Blackwell, Oxford, 2000, p131 and Chris Gosden, Social Being and Time, Blackwell, Oxford, 1994, p119.

- James Fentress and Chris Wickham, Social Memory, Blackwell, Oxford, 1992, ppxxi, and Barbara Mills and William H. Walker, 'Introduction: Memory, Materiality, and Depositional Practice', in Barbara Mills and William H. Walker (eds) Memory 
Work: Archaeologies of Material Practices, School for Advanced Research Press, Santa Fe, New Mexico, 2008, p6.

${ }^{10}$ Lynn Meskell, 'Memory Work and Material Practices', in Barbara Mills and William H. Walker (eds) Memory Work: Archaeologies of Material Practices, School for Advanced Research Press, Santa Fe, New Mexico, 2008, p234.

"Elder Lyle Peters. Personal interview 11 July 2012.

12 Ian Hodder, 'Human-thing Entanglement: Towards an Integrated Archaeological Perspective' in Journal of the Royal Anthropological Institute, vol 17, no 1, 2011, p164. ${ }^{13}$ Bourdieu, op cit, Hodder op cit, p164.

"Barbara Mills and William H. Walker, 'Introduction: Memory, Materiality, and Depositional Practice', in Barbara Mills and William H. Walker (eds) Memory Work: Archaeologies of Material Practices, School for Advanced Research Press, Santa Fe, New Mexico, 2008, pp13-14.

is Elder Laura Purcell, personal interview, 19 July 2012.

${ }^{16}$ Elder Frank and Ina Charlie, personal interview, 8 July 2012.

"I use the term 'memory work' as adopted by Mills and Walker as 'it refers to the many social practices that create memories, including recalling, reshaping, forgetting, inventing, coordinating, and transmitting' Mills and Walker, op cit, p4. ${ }^{18}$ ibid, p4.

${ }^{19}$ Christopher L. Witmore, 'Landscape, Time, Topology: An Archaeological Account of the Southern Argolid, Greece', in Dan Hicks, Laura McAtackney and Graham Fairclough (eds) Envisioning Landscape. Situations and Standpoints in Archaeology and Heritage, Left Coast Press, Walnut Creek, CA, 2007, p195.

${ }^{20}$ Tatiana Argounova-Low, 'Narrating the Road', in Landscape Research, vol 37, no 2, 2012, p201.

${ }^{2}$ Sydney Hunter, pers. comm. 20 July 2010.

${ }^{2}$ Grant Inkster, personal interview, 13 June 2014.

${ }_{23}$ Grant Inkster, personal interview, 11 July 2012.

${ }^{24}$ Jo Lee and Tim Ingold, 'Fieldwork on Foot: Perceiving, Routing, Socializing', in Simon Coleman and Peter Collins (eds) Locating the Field: Space, Place and Context in Anthropology, Berg, Oxford, 2006, p69.

${ }^{25}$ Katrín Lund, 'Landscapes and Narratives: Compositions and the Walking Body' in Landscape Research, vol 37, no 2, 2012, p236.

${ }_{26}$ Jo Vergunst, 'Taking a Trip and Taking Care in Everyday Life', in Tim Ingold and Jo Vergunst (eds) Ways of Walking. Ethnography and Practice on Foot, Ashgate, Aldershot, 2008, p120.

${ }^{27}$ Lee and Ingold, op cit, p73.

${ }^{28}$ Gell, op cit, pp17-18, Erin Gibson, 'Movement, Power and Place: The Biography of a Wagon Road in a Contested First Nations Landscape', in Cambridge Archaeological Journal, vol 25, no 2, 2015, pp419-20.

${ }^{20}$ Rosemary A. Joyce, 'Practice In and As Deposition', in Barbara Mills and William H. Walker (eds) Memory Work: Archaeologies of Material Practices, School for Advanced Research Press, Santa Fe, New Mexico, 2008, p26.

30 Charles Hou, personal interview, 15 July 2012.

${ }^{3}$ Olsen, op cit, p209.

${ }^{32}$ George Kozlovic, personal interview, 15 June 2014.

${ }^{33}$ Judith Butler, Bodies that Matter: On the Discursive Limits of 'Sex', Routledge, New York, 1993 and Barbara Mills and William H. Walker, 'Introduction: Memory, Materiality, and Depositional Practice', in Barbara Mills and William H. Walker (eds) Memory Work: Archaeologies of Material Practices, School for Advanced Research Press, Santa Fe, New Mexico, 2008, p18.

${ }^{3}$ Wendy Ashmore, 'Biographies of Place at Quiriguá, Guatemala', in Brenda J. Bowser and Maria Nives Zedeño (eds) The Archaeology of Meaningful Places, University of Utah Press, Salt Lake City, 2009.

${ }_{35}$ Ashmore, op cit, p16.

${ }^{36}$ Joyce, op cit, p28. 
${ }^{37}$ Argounova-Low, op cit, p201

${ }^{38}$ Gibson, op cit, p418.

${ }^{3}$ Smith, op cit, p50.

*0 British Columbia Ministry of Forests, Lands and Natural Resource Operations, 'Memorandum of Agreement on Trails.' 2013. Available at:

https: / / www.for.gov.bc.ca/archaeology/legislation_agreements_policies_guidelin es_bulletins/memorandum_of_agreement_on_trails.h̆tm (Accessed 25 May, 2014)

"Rodney Harrison, Heritage: $\bar{C}$ ritical Approaches, Routledge, Milton Park, Abingdon, 2013, p4.

"Smith, op cit, pp47-48.

${ }^{3}$ Harrison, op cit, p14, Smith, op cit, pp47-48.

"Harrison, op cit, p4.

${ }^{45}$ Nico Roymans, Fokke Gerritsen, Cor Van der Heijden, Koos Bosma and Jan Kolen, 'Landscape Biography as Research Strategy: The Case of the South Netherlands

Project', in Landscape Research, vol 34, no 3, 2009, p339.

${ }^{4}$ Smith, op cit, p46.

ibid, p66.

« David Carson, Úcwalmícw Newsletter, March 2011.

${ }^{4}$ ibid, p75.

so ibid, p83.

${ }^{51}$ ibid, p56. 